trial to determine whether the combination of problem solving treatment and antidepressant treatment is more effective than either treatment alone.

LMYNORS-WALLIS Consultant psychiatris D H GATH

Reader in psychiatry

A LLOYD-THOMAS

Department of Psychiatry,

University of Oxford

Warneford Hospital

Oxford OX3 7JX

1 Paykel ES, Hollyman JA, Freeling P, Sedgwick P. Predictors of therapeutic benefit from amitriptyline in mild depression: 83-95.

2 Elkin I, Shea MT, Watkins JT, Imber SD, Stosky SM, Collins $\mathrm{JF}$, et al. National Institute of Mental Health treatmen of depression collaborative research program: general effectiveness of treatment. Arch Gen Psychiatry 1989;46: 971-82.

\section{Prevalence of HIV infection}

EdTor,-The figure in Tony Delamothe's report about the anonymous HIV monitoring programme in $1993^{1}$ contains so many graphical distortions ${ }^{2}$ that the unwary may be seriously misled. ${ }^{3}$ The use of four different scales makes comparison impossible unless the reader makes mental conversions back to raw rates. The horizontal boxes carry no data, obscure the mean, and mislead the unwary into believing that they are viewing a horizontal bar chart. People who read the rates off the right hand end of the bars will again overestimate HIV positivity. Finally, the rates for the homosexual and heterosexual populations refer not to the general population but to people attending genitourinary medicine clinics. Readers should not have to read the footnote to the key to find this out. I offer a more honest figure.

These mistakes all have the effect of overemphasising the spread of infection outside high risk groups. This is a pity since the main new message of the survey is that secondary spread among heterosexuals has been slower than expected. I hope that advocates of extending screening to low risk populations are not going to make a habit of using these tricks to buttress their claims. ${ }^{4}$

J G THORNTON Senior lecturer in obstetrics and gynaecology general practice placebo-controlled trial. $f$ Affect Dis 1988;14:

Delamothe T. HIV infection concentrated in London. BMF 1995;310:213. (28 January.)

Tufte ER. The visual display of quantitative information. Cheshire, CT: Graphics Press, 1983.

3 Cartmill RSV, Thornton JG. Obstetric decision making; the effect of varying the presentation of partogram information. Lancet 1992;339:1520-2.

4 Anderson $\mathrm{CM}$, Thornton JG. Screening for cervical cancer. $B M$ 1994;309:953-4.

\section{Emergency care in general practice}

EDITOR,-I am alarmed by the number of authors who consider that emergency medicine and the out of hours service are entirely separate from doctors' obligations to their patients. It is a sad indictment of current standards if the pressures of his work as an NHS general practitioner prevent Andrew Dicker from attending and treating acutely ill patients.' General practitioners seem to have relinquished their raison d'être to other providers, whether they be paramedics, midwives, or pharmacists, all of whom are employed by trusts or businesses.

I completed the five day course of the British Association for Immediate Care some time ago and the three day course more recently. I carry comprehensive set of equipment in my car at all times. This includes oxygen, a defibrillator, and thrombolytic drugs. ${ }^{2}$ None of the equipment was provided by the NHS, and the family health services authority recently declined to give an help towards the cost of replacement defibrillator batteries at $£ 465$ a set, yet I have received more than $£ 10000$ of NHS funds towards computer equipment and other practices have even received television monitors.

I will willingly attend any medical emergency, but I am seldom called by ambulance control to any road traffic accident, case of trauma, or acute medical or obstetric case within my practice area. I have even been the subject of a complaint by the ambulance service because I considered that I was, and a paramedic was not, the better person to accompany my patient on her journey to hospital because she was still unconscious as a result of the ketamine I had given her during extrication from her badly damaged vehicle.

After a minimum of nine years of training every general practitioner is qualified and contracted to provide NHS patients with "all necessary and appropriate personal medical services." It seems, however, that genuinely ill people must now die unnecessarily or languish untreated and in pain for

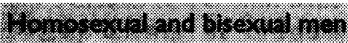

$$
\ldots \ldots \ldots \ldots \ldots \ldots
$$
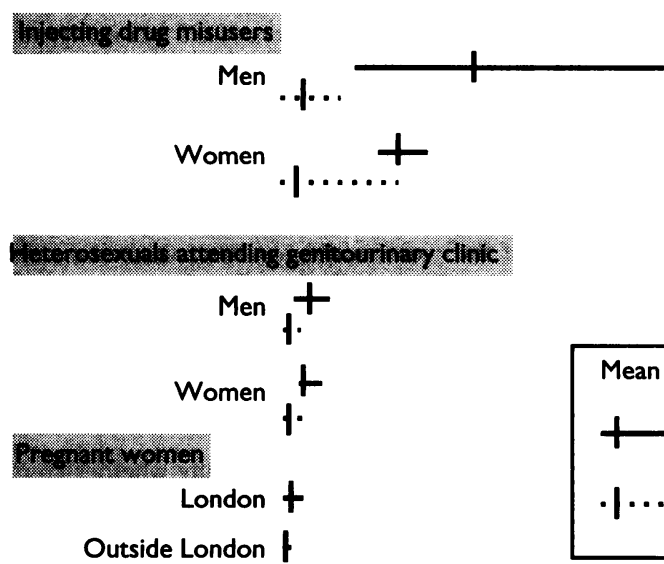

$$
\begin{aligned}
& \text { Mean and centre specific range: } \\
& +\quad \begin{array}{l}
\text { London (London and south east England } \\
\text { for injecting drug misusers) }
\end{array} \\
& \begin{array}{l}
\text { England and Wales } \\
\text { (outside south east) }
\end{array}
\end{aligned}
$$

30 minutes or more while awaiting an ambulance, or possibly for much longer while awaiting a deputising doctor, because early, qualified medical treatment is denied to them unless they live close to a trauma centre. ${ }^{3}$ One author has even stated that defibrillator has never been required in her 17 years in practice. ${ }^{4}$

P D THOMAS General practitioner

Gipping Valley Practice,

Barham,

Ipswich IP6 0AS

1 Dicker A. Emergency care in general practice. BMF 1995;310 735. (18 March.)

2 Thomas PD. Prehospital thrombolysis. BMf 1994;309:871-2.

3 NHS Management Executive. Parenteral administration of prescription only medicines by extended trained ambulance paramedics. Health service guidelines. Leeds: NHSME, 1993:2. (HSG(93)33.)

4 Langfield J. Emergency care in general practice. $B M \mathcal{F} 1995 ; 310$ : 735-6. (18 March.)

\section{Acyclovir for childhood chickenpox}

\section{Has substantial potential service} implications

EDrToR,-Henry $\mathrm{H}$ Balfour Jr fails to take into account the potential service implications of a policy to give acyclovir in childhood chickenpox.' At present most cases of childhood chickenpox do not even come to general practitioners' notice, and those that do are often dealt with over the phone. Once we start actively treating patients, anxiety and expectation will lead to a rapid rise in doctorpatients contacts and requests for home visits, including visits out of hours. The public will not understand the subtle distinction between primary and secondary infections, but it will rapidly get to know that a treatment is available that must be started within 24 hours.

At a time when the demands on general practice are pushing it to breaking point the cyclical chickenpox epidemics would mean that other, more productive use of general practitioners' time would have to wait. Balfour works in a country where home visiting is rare and doctors are paid on an item of service basis. Increased demands lead to increased income. In Britain, however, where general practitioners are paid on a capitation basis and have fixed prescribing budgets, they have to prioritise their time and resources.

Balfour does not suggest that active treatment has any impact on long term outcomes. Trials may suggest that acyclovir reduces the short term "misery index." My six children have all had chickenpox. Three of these were secondary cases, the last of which occurred on a French campsite. I could not argue from practical experience that the misery index was such as to make changing current clinical practice a high priority.

Contributors who advocate active care should consider the long term service implications of their recommendation, especially as it will not be them who deal with the public's panic.

D J PAYNTON

Bath Lodge Practice,

Bitterne Health Centre,

Bitrerne,

Southampton SO18 6BT

1 McKendrick MW, Balfour HH Jr. Acyclovir for childhood chickenpox. BMF 1995;310:108-10. (14 January.)

\section{Author's reply}

EDITOR,-Treatment of an otherwise normal child with chickenpox is probably as controversial in the United States as it is in Britain. Clearly, costbenefit considerations are a-if not the-major issue. Acyclovir shortens the course of chickenpox 